\title{
28. CLAY MINERALOGY OF SITE 397, SOUTH OF CANARY ISLANDS (DSDP LEG 47A)
}

\author{
Hervé Chamley ${ }^{1}$ and Ghislaine Giroud d'Argoud, Geologie Marine, Luminy, 13288 Marseille cx 2, France
}

\begin{abstract}
Clay minerals of Site 397 have mainly a detrital origin, including smectite, attapulgite (= palygorskite), and sepiolite. There is no quantitatively marked influence of volcanism on the clay assemblages. The major lithological units correspond to major mineralogical ones: illite in Lower Cretaceous laminated mudstones (Unit 5), smectite in lower-upper Miocene allochthonous deposits (Units 4, 3 ), and wide-ranged assemblage (smectite, illite, chlorite, kaolinite, mixed-layers, fibrous clays) in upper Miocene to Pleistocene hemipelagic chalks and oozes (Units 2, 1).

The Lower Cretaceous clay assemblage suggests a temperate climate. The tectonic activity, differential settling, and organic environment seem to have a minor influence on the mineralogical composition. During the lower to middle Miocene, the detrital supply is probably derived from the erosion of smectite-rich soils formed under warm conditions with seasonal contrasts in humidity. Additionally, the contribution of pre-Miocene sedimentary rocks influences the clay assemblage. The middle to upper Miocene shows a transitional regime between underlying and overlying mineralogical supplies. From late Miocene to present time, minor mineralogical variations occur without any discernible overall trend. These variations are chiefly due to humidity changes on the nearby African continent: the late Miocene was moderately arid, the Pliocene was more arid, and the late Pliocene and Pleistocene showed a strong alternation of dry and wet stages.
\end{abstract}

\section{INTRODUCTION AND METHODS}

Site 397 is located on the uppermost continental rise off Cape Bojador, south of the Canary Islands $\left(26^{\circ}\right.$ $50.7^{\prime} \mathrm{N}, 15^{\circ} 10.8^{\prime} \mathrm{W} ; 2900 \mathrm{~m}$ water depth). Almost continuously cored to a sub-bottom depth of 1453 meters, Holes 397 and 397A penetrate a 1300-meter Quaternary to lower Miocene section and pass directly into the Lower Cretaceous (see Site 397 Chapter). The mineralogical study of the clay fraction involves 182 samples, about 3 each from Cores 397-1 to 397-56, and 1 each from Cores $397-57$ to $397-93$ and $397 \mathrm{~A}-4$ to $397 \mathrm{~A}-51$.

All samples were subjected to X-ray diffraction analysis of the $<2 \mu \mathrm{m}$ decalcified particles. We observed some of $<8 \mu \mathrm{m}$ non-calcareous particles by transmission electronmicroscopy. The X-ray diffraction method is as described below. The samples are dissociated in water, then decarbonized in $5 N$ hydrochloric acid. The excess acid is removed by successive centrifugations. A microhomogenization leads to deflocculation. The $<2$ $\mu \mathrm{m}$ fraction is collected by decantation using Stokes law, then oriented aggregates are made on glass slides. A CGR $\theta 60$ diffractometer (copper radiation focused by a quartz curved-crystal monochromator) is used to run the X-ray diffraction scans at $1^{\circ} 2 \theta / \mathrm{mn}$. A receiv-

\footnotetext{
${ }^{1}$ Present address: Lille University, BP 36, 59650 Villenuve de'Ascq, France.
}

ing slit of $1.25 \mathrm{~mm}$ permits a better determination of mixed-layer minerals. Four passages are carried out as follows: (a) from $1^{\circ}$ to $15^{\circ} \theta$ on natural sample; (b) from $1^{\circ}$ to $7^{\circ} \theta$ on glycolated sample; (c) from $1^{\circ}$ to $7^{\circ} \theta$ on sample heated for 2 hours at $490^{\circ} \mathrm{C}$; and (d) from $12^{\circ}$ to $14^{\circ} \theta$ on hydrazine-hydrated sample. Semiquantitative evaluations are based on the peak heights and areas (Chamley, 1971). The heights of 001 illite and chlorite peaks (diagram of glycolated sample) are taken as references. Compared to these values, smectite, attapulgite, and irregular mixed layers are corrected in addition to peak height, and well-crystallized kaolinite is corrected in diminution. The balance between chlorite and kaolinite results from peak heights ratio $(3.54 \AA$ and $3.58 \AA$, respectively); when this ratio is one, the amount of chlorite is assumed to be two times that of kaolinite. Final data are given in percentages, the relative error being about \pm 5 per cent.

\section{RESULTS AND DISCUSSION}

Five lithological units occur showing three main clay assemblages (Figure 1). The data and their significance are considered in chronological order (Figure 2).

\section{Lower Cretaceous-Lithologic Unit 5}

Unit 5 ( 1300 to $1453 \mathrm{~m}$ sub-bottom, Cores 34 to 52 of Hole 397A) consists of a Lower Cretaceous (Hauterivian), well-laminated mudstone sequence with thin 

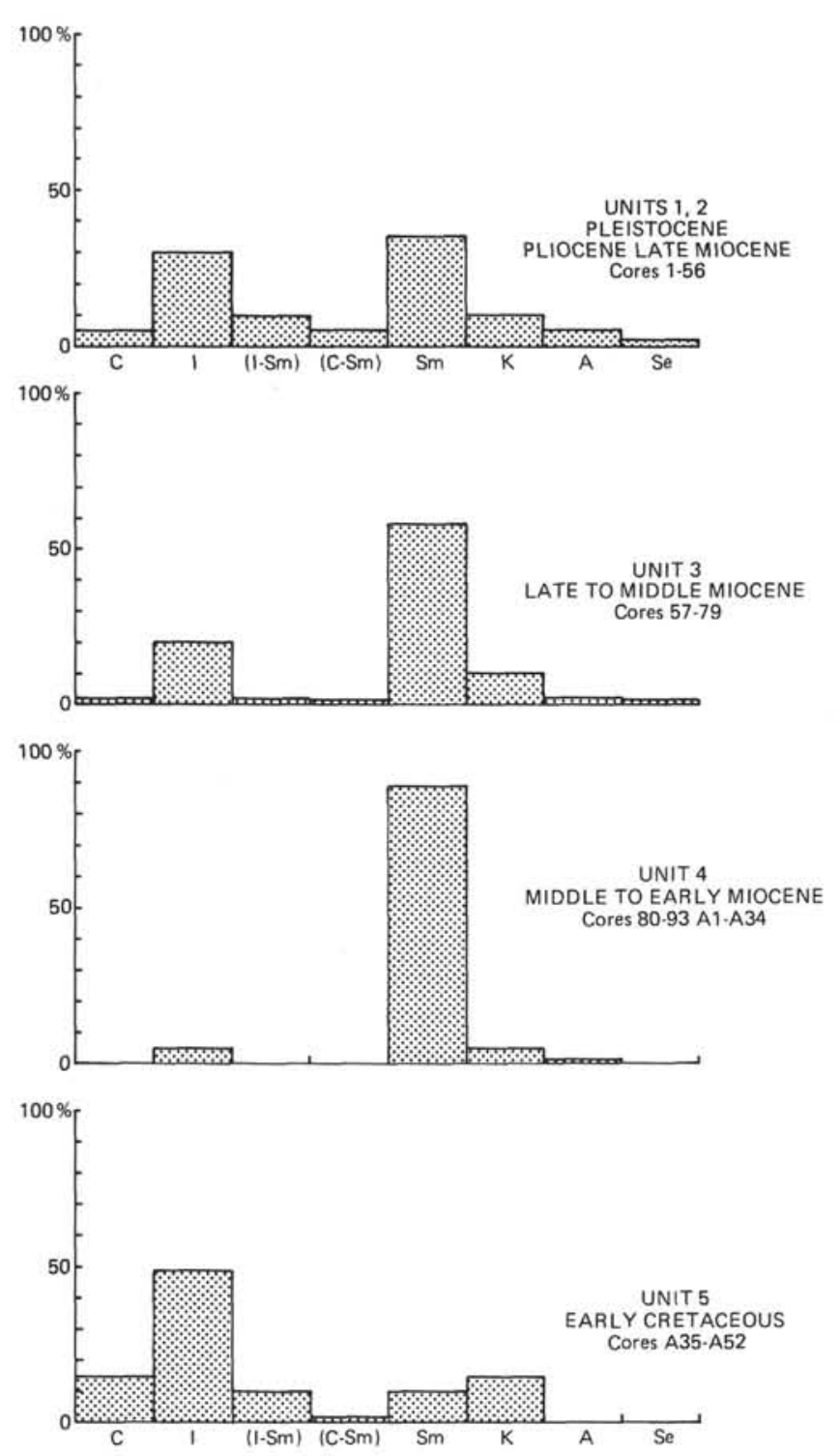

Figure 1. Main clay assemblages.

siderite intercalations (Einsele and von Rad, this volume). The mudstones that underwent our mineralogical analysis are, after decarbonization, variable in color with mixes of brown, yellowish brown, pink, or gray.

The clay mineralogy shows the predominance of well-crystallized illite (averaging $50 \%$ of clay minerals, ranging between 45 and $60 \%$ ). Other phyllosilicates are kaolinite (15\%), well-crystallized chlorite (10\%), irregular mixed-layers ( 5 to $20 \%$, chiefly illite-smectite), and badly crystallized smectite (5 to $15 \%$, exceptionally $30 \%$ ). Quartz is common in the clay fraction; goethite is fairly rare; feldspars, amphiboles, and pyrites occur rarely.

These clay assemblages point to a typically detrital origin. They indicate the erosion of crystalline or metamorphic rocks (illite, chlorite), more or less weathered by pedogenesis (degraded smectite, mixed layers, kaolinite). Sources of this detrital material are difficult to establish because of the lack of onshore and offshore equivalents (see Guieu, 1976). The oldest sediments recovered from the Lower Cretaceous of Site 398 (DSDP Leg 47B, west of the Iberian Peninsula) are younger than those at the base of Site 397 ; moreover, its clay mineralogy differs radically from that identified here (major mineral $=$ smectite; Chamley et al., this volume, Part 2).

Shipboard lithologic studies (Site 397 Chapter) suggest a slope setting on a prodelta under oxygen-depleted conditions, at a minimum depth of deposition greater than 200 to 300 meters (Einsele and von Rad, this volume). This interpretation presumes an African main source for the detrital minerals. This agrees with other observations (Müller and Rothe, 1975) and is corroborated by clay mineralogy: the Precambrian to Paleozoic shield is rich in illite and sometimes chlorite, which characterizes the clay fraction of Unit 5 . Such an erosion of the continental basement does not seem to be influenced by tectonic activity because the western African craton is very stable (Dillon and Sougy, 1974). The cause of the clay mineral assemblage could be the continental climate at the time of deposition. The abundant and well-preserved primary minerals, the presence of irregular mixed layers, and degraded smectite suggest moderate weathering and hydrolysis. That means a moderate development of soils in the alluvial basins. The deltaic affinity and the irregular rythmicity of the Cretaceous deposits point to rapid sedimentation. This indicates appreciable rainfall and significant river supply. Thus, we propose as a working hypothesis for the Hauterivian period, the occurrence of a temperate-typed climate, with moderate temperature and humidity.

Specific sedimentary conditions can be presumed to explain the Lower Cretaceous clay assemblages, but their influence on the mineralogy is probably not essential. Deltaic sedimentation, as at Site 397, often shows differential settling that favors illite, chlorite, and kaolinite at the expense of smectite in strong hydrodynamical zones (Porrenga, 1966; Chamley, 1971). But such a settling is of minor significance and cannot explain the differences between Sites 397 and 398, or between the Lower Cretaceous and the lower Miocene of Site 397. Similar deltaic deposits exist at other drill sites of the eastern Atlantic margin (Legs 47B and 48; unpublished data), where smectite content is very high ( 80 to $100 \%$ ). Moreover, no marked mineralogical sorting exists in the samples studied here, although they correspond to unstable conditions of sedimentation. Another explanation of the Cretaceous assemblages might be based on the organic matter content of the sediments (Unit 5 contains organic material, primarily plant remains). The organic matter sometimes is opposed to the conservation of clay particles such as smectite, which are small and characterized by high-exchange properties (Chamley, 1971; Sigl et al., 1978). One could envisage a partial destruction of smectite by organic acids in this special environment. In fact, the total amount of organic matter is fairly low at Site 397 (Tissot et al., this volume), although it is diagenetically more mature in the Cretaceous than during the 


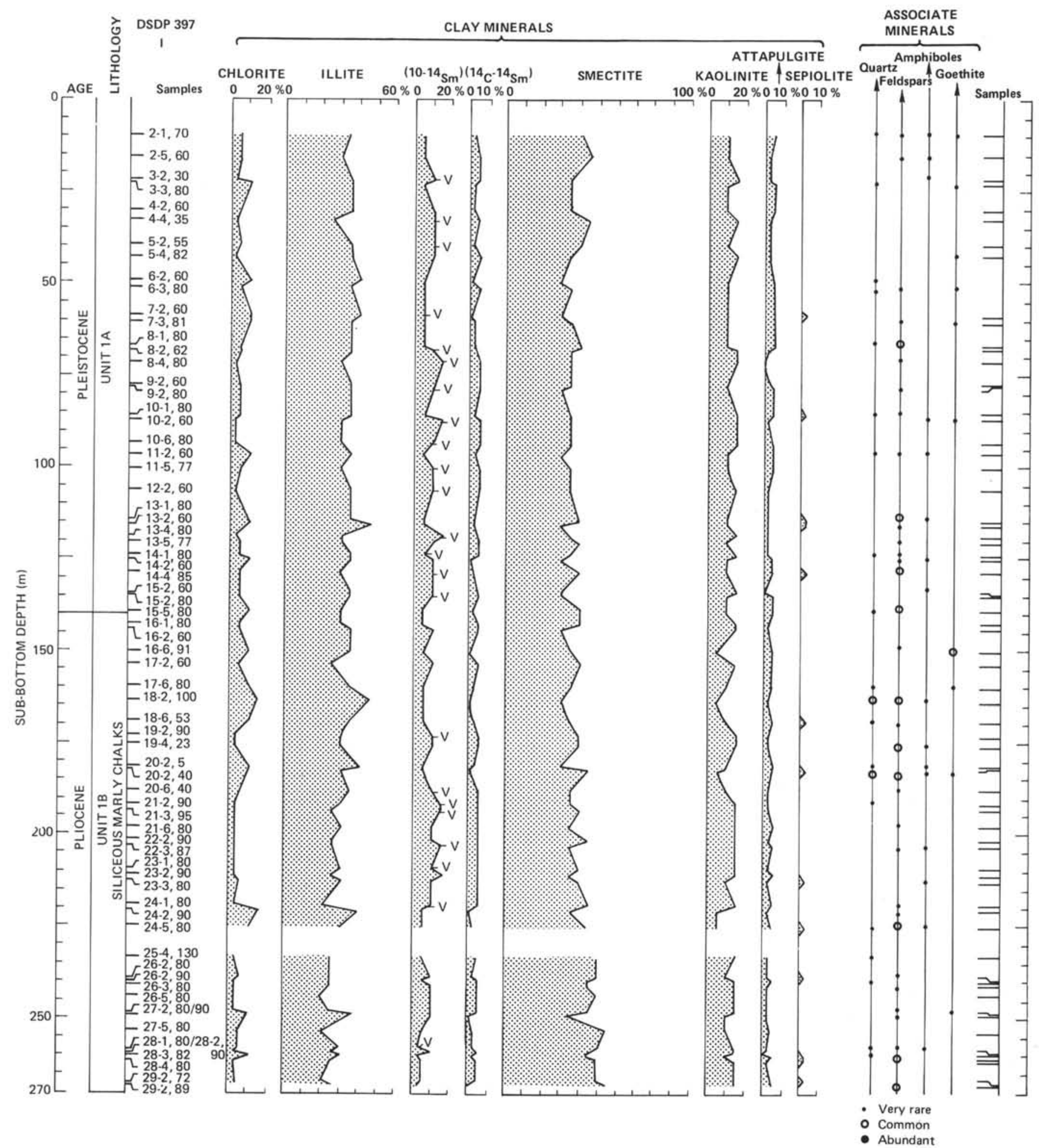

Figure 2. Clay mineralogy of Site $397(0-270 \mathrm{~m}, 270-540 \mathrm{~m}$, and 540-1453 m sub-bottom depth). $n . b .: \mathrm{V}=$ presence of illitevermiculite mixed-layers.

Miocene. This was revealed by the relatively light color of decarbonized clay suspensions. No systematic relationship exists between the color of the sediment and the amount or crystallinity of smectite, in contrast to Mediterranean sapropelic sediments (Sigl et al., 1978). All these observations point to a weak or nonexistent clay diagenesis being influenced by the organic matter. 


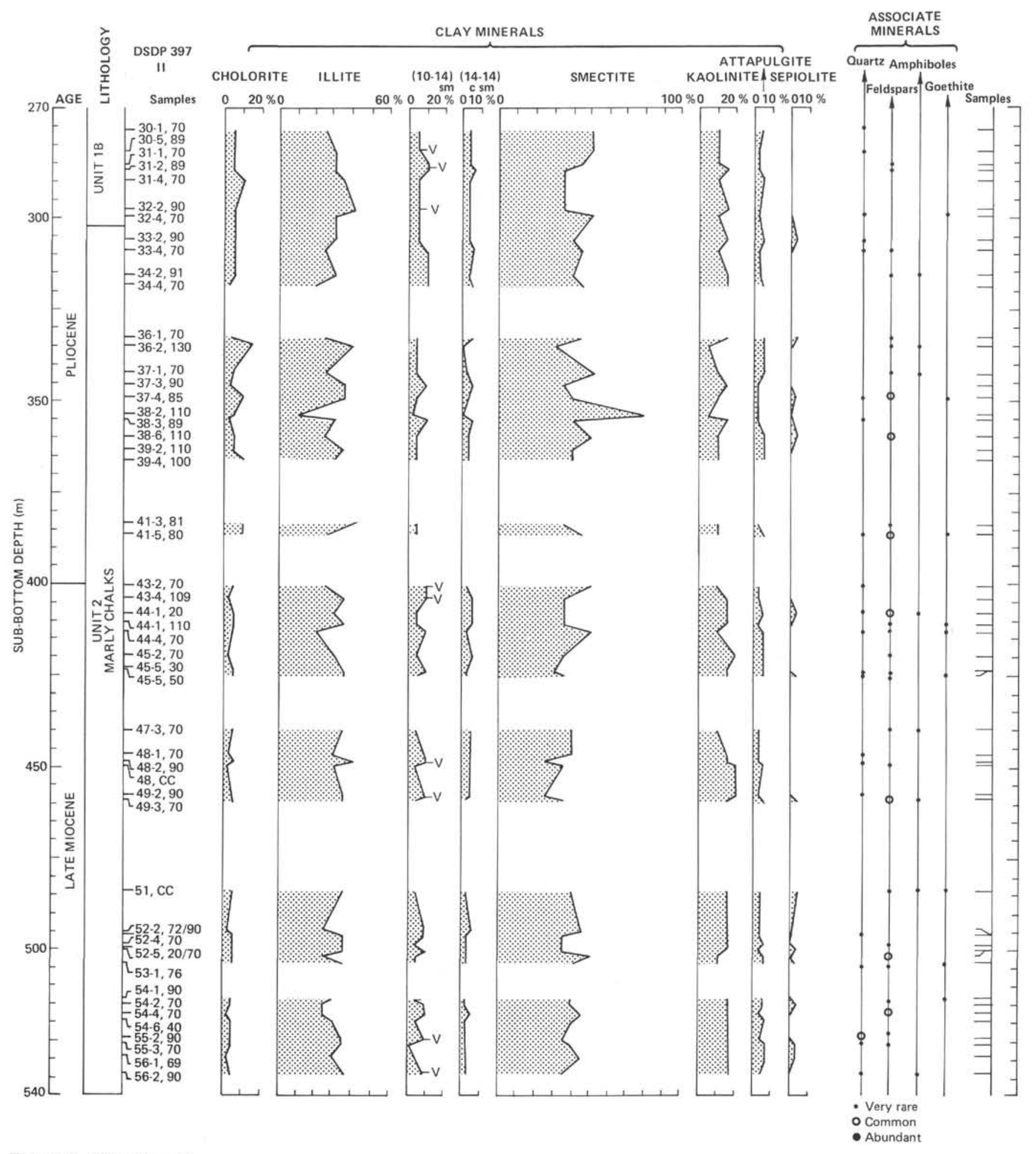

Figure 2. (Continued).

\section{Lower to Middle Miocene-Lithologic Unit 4}

Unit 4 , occurring after a major hiatus of about 100 million years, consists of amalgamated debris flow and slump deposits transported by creep, avalanching, and gravity-controlled currents ( 752 to $1300 \mathrm{~m}$, Cores 4 to
33 in Hole 397A and Cores 80 to 104 in Hole 397). This section contains locally thick volcaniclastic sandstones and conglomerates, and is 80 to 90 per cent allochthonous (see Site 397 Chapter).

The clay mineralogy is remarkably homogeneous relative to the high sedimentological diversity. Highly 


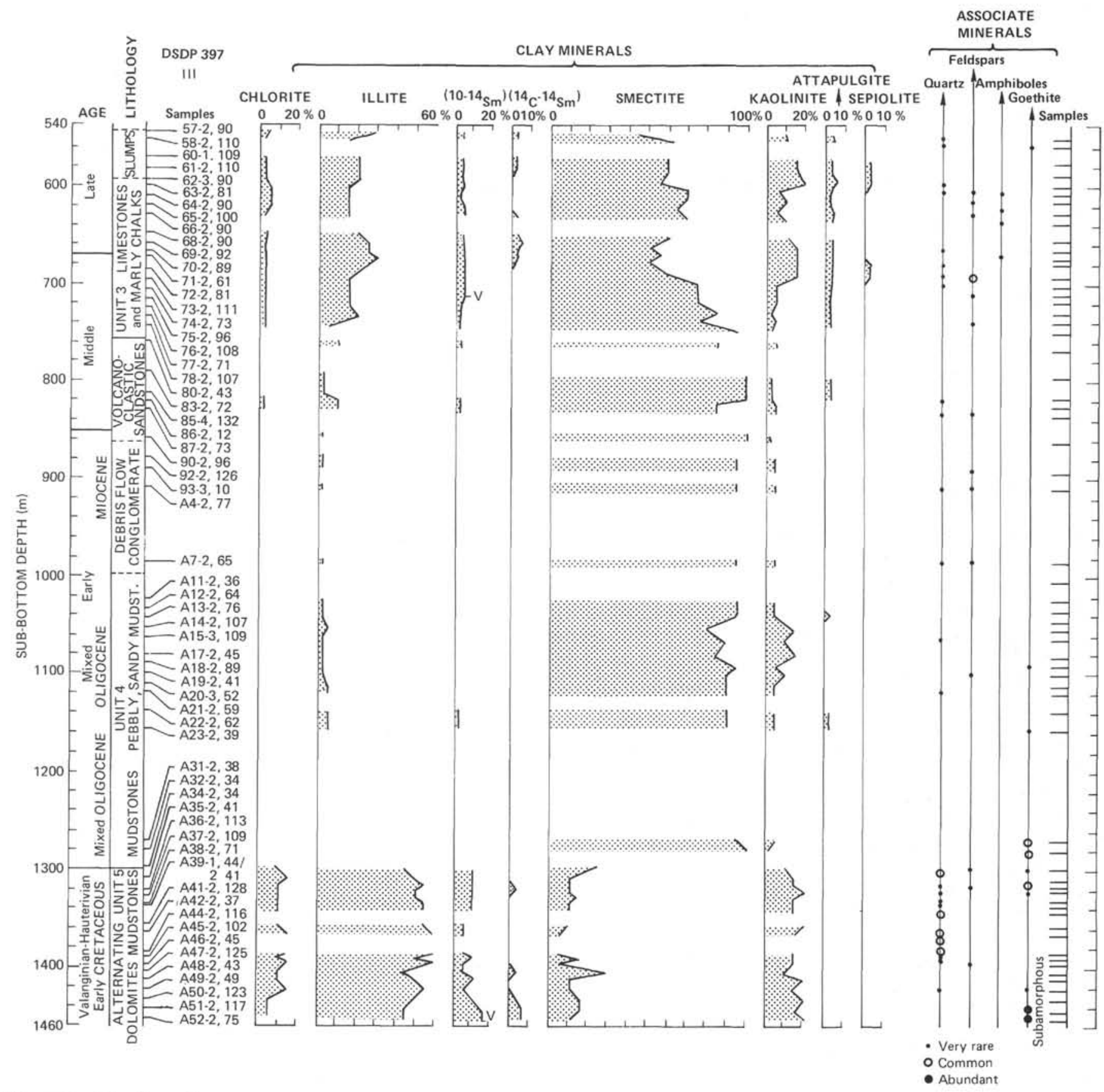

Figure 2. (Continued).

crystallized smectite is the main mineral, comprising between 85 and 100 per cent with an average of 90 per cent. Associate minerals are kaolinite (5\%, locally 10 to $15 \%$ ) and fairly well-crystallized illite (traces to $5 \%$ ). Chlorite and attapulgite ( = palygorskite) occur episodically in low amounts, as to mixed-layer clays. Quartz, feldspars, goethite, and pyrite are rarely present in the clay fraction. The following paragraphs present our observations about the clay composition.

The origin of smectite is an essential question. The proximity of Site 397 to the Canary and Cape Verde islands leads initially to the presumption of a volcanic origin. The base of Unit 4 (Cores 31 and 32 of Hole $397 \mathrm{~A}, 1267.5$ to 1286.5 sub-bottom) is one of the zones very rich in smectite. This zone does not contain volcanic material; volcanic fragments first appear much later (Cores 86 and 87,830 m, about 16 m.y.B.P.), coinciding with the major uplift of the Canary islands about 13 to 18 m.y.B.P. (Schmincke et al., this volume). Cores 86 and 87 show a relative diminution of smectite. The major volcaniclastic beds (Cores 79 to 81,84 and 85 ) have not been studied here for clay mineralogy because of their high degree of consolidation. But the intercalated and overlying layers fre- 
quently contain volcanic ashes, which do not seem to be correlated with the amount of smectite. The uppermost lithologic units of Site 397 contain variable amounts of volcanic particles, but the amount of smectite is comparable in both cases. All these observations show that an autochthonous transformation of volcanic materials cannot be the main origin of smectite in the case of Site 397. This conclusion agrees with the perturbed character and the rapidity of sedimentation, both of which are unfavorable to geochemical exchanges. Smectite, therefore is chiefly a detrital mineral. The alteration of volcanic material, especially in subaerial conditions, probably contributed to the smectite supply from the period of uplift of the Canary Islands, but it is not the principal origin.

Smectite can be inherited from various continental rocks and soils. Several studies on Upper Cretaceous and Tertiary series of the Atlantic Ocean show the importance of both sources (DSDP Legs 14, 40, 44, 47B, 48, and 50; Diester-Haass and Chamley, in press; Pastouret et al., 1978; Chamley et al., this volume, Part 2; Chamley, unpubl. data). Soils seem to be chiefly responsible for the supply of the clay fraction in sedimentary rocks, which could be ulteriorly eroded and reworked. The pedogenic formation of smectite in great amounts implies a rather warm climate with seasonal contrasts in humidity. Analogous conditions exist at the present time in badly drained zones of tropical to Mediterranean climatic belts (Paquet, 1969). The abundance of detrital smectite in the sediments have suggested the occurrence of such conditions during early Neogene time in continental areas close to Site 397 . Relative to pre-Miocene rocks, numerous studies show the frequency and the abundance of smectite in the clay fraction (aforementioned references; also see Millot, 1964). Oligocene strata are peculiarly rich in smectite and could contribute to the detrital clays at Site 397 . That agrees with the Oligocene-mixed sediment recognized at the base of Unit 4 (Cores 16 to 33 in Hole 397A; see Site 397 Chapter).

The great variability of the nature and distribution of lithological facies (Arthur, this volume) does not correspond to marked variations in the clay fraction of the deposits (Figure 2). Such an independence suggests a single or slightly variable origin for the detrital sedimentary components.

Attapulgite ( = palygorskite), rarely present at Site 397 and then only in traces, has the same main detrital origin as other clay minerals. Scattered among typical inherited minerals (illite, chlorite, kaolinite) and not dependent on lithology or smectite abundance, attapulgite chiefly originates from the erosion of sedimentary rocks outcropping on the African shield. The main sources have an Eocene age (Millot, 1964; Chamley, 1971; also see von Rad and Rösch, 1972; Pimm and Hays, 1972) and contribute to marine sedimentation until the present time (Chamley et al., 1977).

Kaolinite locally increases in Cores 13 to 19 in Hole 397A, perhaps because of a greater supply from upstream zones of alluvial basins where the mineral is preferentially formed by pedogenesis. Illite and partly chlorite increase at the same time that the first ashes occur (Cores 86 and 87 ), just before the large volcaniclastic arrival. This temporary change may reflect epeirogenic movements of the basement, in relation to the volcanic events.

\section{Middle Miocene to Pleistocene-Lithologic Units 3 to 1}

Unit 3 contains limestones and marly chalks with slump structures (Core 61 to 79 in Hole 397), then sub-continuous slump structures (Cores 57 to 61 ). Unit 2 is comprised of marly nannofossil oozes, chalks, and limestones (Cores 33 to 56). Unit 1 consists mainly of siliceous nannofossil oozes (Cores 1 to 33 ).

As shown by the lithology, Unit 3 (middle to upper Miocene) is a transitional zone between allochthonous Unit 4 and autochthonous Units 1 and 2. An analogous transition occurs in the clay mineralogy, studied in 20 samples. Cores 57 to 79 show a transition from smectite-rich sediments (lower to middle Miocene) to sediments with diversified clay assemblages (upper Miocene-Pliocene-Pleistocene: illite, chlorite, smectite, irregular mixed-layers, kaolinite, and detrital associate minerals). Apparently, lithologic changes are closely related to mineralogical ones. These clay variations can have two causes, possibly concomitant. The first cause is the progressive diminution in supply of smectite-rich reworked materials, whose age is pre-Miocene or early Miocene. Secondly, these clay variations may be the result of progressive worldwide cooling identified in the later Miocene (see Ryan et al., 1974), and responsible for a decrease in pedogenic processes and an increase in high-latitude supply. Such a cooling is revealed in contemporaneous clay sedimentation at several other DSDP sites (Legs 40, 47B, 48; Chamley, unpublished) by a comparable increase in the content of primary minerals (illite, chlorite, quartz, feldspars, amphiboles) compared to smectite. The biostratigraphical hiatus occurring between middle and late Miocene (Cores 72 and 73 ) is mineralogically marked by a strong increase in the terrigenous supply from upstream continental drainage zones during a wet period. Such a phenomenon, indicating a high-energy stage, could have been partially responsible for the erosion of the missing sediments.

Hemipelagic Units 2 and 1 (upper Miocene-Pliocene-Pleistocene), studied in 122 samples, do not show any significant difference in clay mineralogy. The compositional averages are as follows: $40 \%$ illite, $30 \%$ smectite, $10 \%$ kaolinite, $10 \%$ irregular mixed-layers (illite-smectite and chlorite-smectite, sometimes illite-vermiculite), $5 \%$ chlorite, and $5 \%$ attapulgite. Sepiolite is locally present in traces. Associate minerals are chiefly quartz, feldspars, amphiboles, and goethite: these are fairly more abundant in Subunit A than in B. As discussed earlier, all the clay minerals are detrital and mainly inherited from African terrain, including sepiolite whose origin is the same as that of attapulgite (mainly lower Tertiary sedimentary rocks; also see Chamley et al., 1977; Diester-Haass and Chamley, in press). It is not possible to assume an authigenic origin for these clay minerals, because their distribution is in- 
dependent of lithology, presence of volcanic components, and depth of burial.

Clay variations in Units 1 and 2 follow two markerminerals, chlorite and mixed layers. When chlorite increases, an increase in attapulgite and partly in sepiolite, illite, and non-clay minerals (quartz, feldspars, amphiboles, and goethite) is also observed. When mixed-layers increase, kaolinite and smectite often increase, while the former group decreases. These variations are discussed in a climatological context, in a study conducted with L. Diester-Haass on coarse and fine fractions of 73 samples (Chamley and DiesterHaass, this volume). The main conclusions are in the following paragraphs.

The chlorite relative abundance bears an inverse relationship to continental humidity, which governs the rock's weathering and the hydrolysis of primary minerals. On the other hand, the group of mixed-layers varies parallel to the intensity of hydrolysis and pedogenesis. Mineralogical changes along the hemipelagic sequence reflect humidity changes in western Africa, as do changes in percentages of terrigenous coarse fraction and desert quartz numbers.

The late Miocene appears to have been less arid than the Pliocene, perhaps because of a different distribution of humidity in the seasonal cycle. There is no smectite-rich stage as in Mediterranean and other Atlantic sites (Chamley et al., 1978; Diester-Haass and Chamley, in press), maybe because of local effects of Atlas tectonism (Dillon and Sougy, 1974).

The Pliocene had a constant arid character as deduced from coarse fraction work but, based on clay fraction analysis, a variable one with dominantly arid conditions. The cause of the discrepancy seems to be a moderate continental humidity, high enough to permit the formation and transport of fine minerals but not of $>40 \mu \mathrm{m}$-sized particles. Starting from the late Pliocene world cooling (about 3 m.y.B.P.) and during the entire Pleistocene, both sedimentary components are influenced by relatively high transport energies and together point to an alternation of wet and dry climatic periods in the Sahara.

\section{ACKNOWLEDGMENTS}

We thank the scientific shipboard party of Leg 47A for providing samples for the shore-based investigations. We are grateful to CNEXO, France, for the financial support of this study (Grant No. 76/5320). Technical assistance was given by R. Kerbrat, Brest, and by C. H. Froget, Marseille: Scientific assistance and reviews are due to L. Diester-Haass, M. Melguen, U. von Rad, V. Riech, and H. Rosch, who are gratefully acknowledged.

\section{REFERENCES}

Chamley, H., 1971. Recherches sur la sedimentation argileuse en Mediterrane, Sci. géol., Strasbourg, France, Mém. 35 .
Chamley, H., Diester-Haass, L., and Lange, H., 1977. Terrigenous material in East Atlantic sediment cores as an indicator of NW African climates, Meteor Forschungsergebnisse, v. 26, p. 44-59.

Chamley, H., Dunoyer de Segonzac, G., and Mélières, F., 1978. Clay minerals in Messinian sediments of Mediterranean area. In Hsü, K. J., Montadert, L. C., et al., Initial Reports of the Deep Sea Drilling Project, v. 42, Part 1: Washington (U.S. Government Printing Office), p. 389.

Diester-Haass, L. and Chamley, H., in press. Neogene paleoenvironment investigations off NW Africa (DSDP Leg 14 ) by means of a coarse and clay fraction analysis, $J$. Sediment. Petrol.

Dillon, W. P. and Sougy, J. M. A., 1974. Geology of West Africa and Canary and Cape Verde Islands. In Nairn, E. M. and Stehli, F. C. (Eds.), The ocean basins and margins: The North Atlantic, v. 2, p. 315-390

Guieu, G., 1976. Les bassins à évaporites de la marge ouestafricaine du Maroc à l'Angola, Départm. Geol. Fac. Sci., University of Dakar, Sénégal, Rap. 32.

Millot, G., 1964. Géologie des Argiles: Paris (Masson Ed.).

Müller, C. and Rothe, P., 1975. Nanno-plankton contents in regard to petrological properties of deep-sea sediments in the Canary and Cape Verde areas, Mar. Geol., v. 19, p. 259-273.

Paquet, H., 1969. Evolution géochimique des minéraux argileux dans les altérations et les sols des climats méditerranéens et tropicaux à saisons contrastées, Mém. Serv. Carte géol. Alsace-Lorraine, Strasbourg, no. 30.

Pastouret, L., Auffret, G. A., and Chamley, H., 1978. Microfacies of some sediments from the North Western Atlantic: paleoceanographlc implications (Leg 44 DSDP). In Benson, W. F., Sheridan, R. E., et al., Initial Reports of the Deep Sea Drilling Project, v. 44: Washington (U.S. Government Printing Office), p. 477-502.

Pimm, A. C. and Hayes, D. E., 1972. General synthesis. In Pimm, A. C., Hayes, D. E., et al., Initial Reports of the Deep Sea Drilling Project, v. 14: Washington (U.S. Government Printing Office), p. 955-975.

Porrenga, D. H., 1966. Clay minerals in recent sediments of the Niger delta, Clays and Clay Min., v. 14, p. 221-233.

von Rad, U. and Rösch, H., 1972. Mineralogy and origin of clay minerals, silica and authigenic silicates in Leg 14 sediments. In Pimm, A. C., Hayes, D. S. et al., Initial Reports of the Deep Sea Drilling Project, v. 14: Washington (U.S. Government Printing Office), p. 727-751.

Ryan, W. B. F., Cita, M. B., Rawson, D., Burckle, L. H., and Saito, T., 1974. A paleomagnetic assignment of Neogene stage boundaries and the development of isochronous datum planes between the Mediterranean, the Pacific and Indian Oceans in order to investigate the response of the world ocean to the mediterranean "salinity crisis," Riv. Ital. Paleontol., v. 80, p. 631-688.

Sigl, W., Chamley, H., Fabricius, F., Giroud d'Argoud, G., and Müller, J., 1978. Sedimentology and environmental conditions of sapropels. In Hsü, K. J., Montadert, L. C., et al., Initial Reports of the Deep Sea Drilling Project, v. 42, Part 1, Washington (U.S. Government Printing Office), p. 421 . 